\title{
KUALITAS FESES DAN PRODUKSI BIOGAS KAMBING KEJOBONG MUDA DAN DEWASA YANG DI BERI PAKAN DENGAN IMBANGAN KONSENTRAT DAN HIJAUAN YANG BERBEDA
}

\section{FECES QUALITY AND BIOGAS PRODUCTION OF BUCK KID AND BUCK KEJOBONG GOAT FECES FED DIFFERENT RATIO OF CONCENTRATE AND FORAGE}

\author{
Akhmad Alfiyan Nurahman, Nadlirotun Luthfi, Sutaryo ${ }^{1}$, Agung \\ Purnomoadi \\ Program Studi Peternakan, Departemen Peternakan, Fakultas \\ Peternakan dan Pertanian, Universitas Diponegoro \\ 1E-mail: soeta@lecturer.undip.ac.id
}

\begin{abstract}
The aim of this study was to evaluate the effect of different ratio of forage and concentrate on the feces quality and its biogas production. Eight buck kid $( \pm 5$ months old) with initial body weight $14.03 \pm 1.46 \mathrm{~kg}(\mathrm{CV}: 10.43 \%)$ and eight buck of kejobong ( \pm 9 monts old) with average initial body weight $22.32 \pm 1.99$ $\mathrm{kg}$ (CV: 8.92\%) were used in this study. The ration was prepared in the forms of pellets that contains of forage (Panicum muticum) and concentrate (cassava, soybean meal, mollases, rice bran and mineral mix) in different ratio. The experiment was arranging according to nested design that feed treatment nested to animal age. The feed treatments were $\mathrm{T} 1: 30 \%$ concentrate and $70 \%$ forage and $\mathrm{T} 2: 30 \%$ forage and $70 \%$ concentrate. The observed variables were feces production, feces quality and its biogas production. The data were tabulated and analyzed with $\mathrm{F}$ test. The study result showed that biogas production of feces from $\mathrm{T} 1$ was significantly $(\mathrm{P}<0.05)$ higher than that in $\mathrm{T} 2$. Biogas production of feces from young goat showed the same phenomenon as well. It can be concluded that biogas production derived kid buck feces is higher than that in buck probably due to the digestive tract of this anmial still in development stage.
\end{abstract}

Key words: biogas, feses, kambing, perbedaan umur

\begin{abstract}
ABSTRAK
Tujuan dari penelitian ini yaitu untuk mengkaji produksi biogas dari feses Kambing Kejobong muda dan dewasa dengan imbangan konsentrat dan hijauan yang berbeda. Materi yang digunakan yaitu 8 ekor kambing Kejobong jantan umur muda ( \pm 5 bulan) dengan bobot badan (BB) awal rata-rata 14,03 $\pm 1,46 \mathrm{~kg}$ $(\mathrm{CV} 10,43 \%)$ dan 8 ekor kambing dewasa ( \pm 9 bulan) dengan BB awal rata-rata $22,32 \pm 1,99 \mathrm{~kg}$ (CV 8,92\%). Pakan diberikan dalam bentuk pellet terdiri dari hijauan rumput Kolonjono (Panicum muticum) dan konsentrat (gaplek, bungkil kedelai, molases, dedak padi dan mineral mix). Penelitian menggunakan metode Nested Design yaitu perlakuan pakan tersarang dalam perlakuan umur. Perlakuan pakan T1 tersebut adalah (30\% konsentrat :70\% rumput), sedangkan pakan T2
\end{abstract}


(30\% rumput :70\% konsentrat). Variabel yang diamati yaitu produksi feses, kualitas feses ternak dan produksi biogas. Data yang diperoleh dianalisis dengan uji F. Hasil penelitian menunjukkan bahwa produksi biogas berbeda nyata, produksi biogas pada $\mathrm{T} 1$ lebih tinggi dibandingkan produksi biogas $\mathrm{T} 2(\mathrm{P}<0.05)$. Produksi biogas pada perlakuan umur menunjukan hasil umur muda lebih tinggi dibandingkan pada umur dewasa. Simpulan yang dapat diambil dari penelitian ini adalah kambing muda yang diberi pakan perlakuan $\mathrm{T} 1$ menghasilkan produki biogas yang tinggi.

Kata kunci: biogas, feces, goat, age difference

\section{PENDAHULUAN}

Kambing Kejobong merupakan Kambing persilangan antara Kambing Kacang dengan Kambing Peranakan Etawa (PE). Keunggulan Kambing Kejobong yaitu laju pertumbuhannya cepat, dan daging yang tidak berbau seperti daging kambing pada umumnya (Kusuma et al., 2013). Kambing kejobong merupakan salah satu kambing lokal yang berpotensi untuk dijadikan pemenuhan sumber kebutuhan protein hewani di Indonesia. Produktivitas kambing kejobong masih rendah. Peternak hanya menggunakan pakan rumput untuk pemenuhan pakan. Pemberian pakan dengan rumput menjadikan proses pemeliharaan ternak untuk mencapai bobot potong yang diharapkan akan memakan waktu yang lama. Dari permasalahan tersebut maka perlu ditemukan solusi yang tepat.

Solusi yang dapat diterapkan pada permasalahan ini yaitu dengan melakukan penggemukan dini pada kambing. Tujuan dilakukan penggemukan dini yaitu untuk mempersingkat masa pemeliharaan dari ternak. Pada penggemukan dini cempe masih pada tahap pertumbuhan sehingga perlu ditunjang dengan pakan yanng nutrisinya dapat memenuhi kebutuhan cempe. Siregar (2018) menyatakan bahwa cempe yang belum pubertas laju pertumbuhannya akan mengalami peningkatan. Pada cempe laju pertumbuhan jaringan yang optimal terjadi pada tulang dan otot sementara pada lemak masih belum optimal, sehingga dengan dilakukan penggemukan dini maka akan dihasilkan daging dengan lemak yang masih rendah. Nabila (2017) menyatakan bahwa domba sebelum pubertas akan megalami peningkatan pertumbuhan pada jaringan otot dan tulang. Solusi kedua yang dapat diambil yaitu dengan memberikan pakan dengan imbangan antara konsentrat dan hijauan yang sesuai dengan kebutuhan ternak. Proses pertumbuhan harus didukung dengan pemenuhan kebutuhan nutrisi pakan. Pemberian pakan dengan tambahan konsentrat menjadikan penyerapan nutrien akan lebih banyak sehingga untuk mencapai bobot potong akan lebih singkat di banding hanya dengan menggunakan rumput. Nuraeni (2014) menyatakan pakan konsentrat kandungan seratnya lebih sedikit sehingga akan lebih mudah dicerna oleh ternak.

Pada kambing usia muda penyerapan nutrisi belum optimal karena saluran pencernaannya belum terbentuk dengan sempurna. Marhaeniyanto dan Susanti (2017) menyatakan bahwa kondisi pencernaan kambing muda masih dalam masa pertumbuhan sehingga penyerapan pakan belum maksimal. Kecernaan bahan pakan yang masih rendah akan mengakibatkan feses yang dikeluarkan masih 
memiliki bahan organik yang lebih tinggi dibanding kambing dewasa. Imbangan pakan yang berbeda juga akan menghasilkan bahan organik dari feses yang berbeda karena perbedaan kandungan protein dan energi yang berbeda dari pakan tersebut. Perbedaan dari kualitas feses dari pakan yang berbeda akan menghasilkan potensi biogas yang berbeda dan perbedaan umur juga akan menghasilkan potensi biogas yang berbeda juga. Produksi biogas dipengaruhi oleh aktivitas mikroganisme dan ketersediaan bahan organik dalam feses. Hal ini sesuai dengan pendapat Dewi dan Dewi (2014) bahwa kandungan bahan organik berpengaruh terhadap produksi biogas.Tujuan dari penelitian ini yaitu untuk mengkaji produksi biogas dari feses Kambing Kejobong muda dan dewasa dengan imbangan konsentrat dan hijauan yang berbeda. Manfaat dari penelitian adalah untuk mengetahui produksi biogas dari feses yang dihasilkan oleh Kambing Kejobong muda dan dewasa dengan imbangan konsentrat hijauan yang berbeda.

\section{METODE PENELITIAN}

\section{Ternak}

Penelitian mengenai Produksi Biogas dan Kualitas Feses Kambing Kejobong, menggunakan Kambing Kejobong jantan sebanyak 16 ekor yang terdiri dari, 8 ekor kambing muda ( \pm umur 5 bulan) dan bobot badan awal rata-rata $14,03 \pm 1,46 \mathrm{~kg}$ (CV 10,43\%) 8 ekor dewasa (umur 8 bulan) dengan bobot badan awal rata-rata $22,32 \pm 1,99 \mathrm{~kg}$ (CV 8,92\%). Pakan yang digunakan pada penelitian ini yaitu hijauan rumput Kolonjono (Panicum muticum) dan konsentrat. Konsentrat tersusun dari bahan pakan gaplek, bungkil kedelai, molases, dedak padi dan mineralmix.

Kandang yang digunakan yaitu kandang individu tipe panggung terbuat dari bahan dasar besi dan kayu. Kandang dilengkapi dengan tempat pakan dan minum dari ember plastik.

\section{Rancangan Percobaan}

Rancangan percobaan yang digunakan dalam penelitian ini yaitu Rancangan Tersarang (Nested Design), umur kambing sebagai faktor A (sarang) dan perlakukan pakan sebagai faktor B (tersarang) sehingga taraf B tersarang dalam taraf A. Faktor A adalah umur muda (UM) dan umur dewasa (UD), sedangkan faktor B adalah perlakuan pakan, yaitu

T1 : 70\% Rumput : 30\% Konsentrat

T2 : 30\% Rumput : 70\% Konsentrat

Pakan

Komposisi konsentrat terdiri dari gaplek 6\%, bungkil kedelai $45 \%$, dedak $42 \%$, molasses $6 \%$, dan mineral mix 1\% dengan kandungan PK 18,07\% dan TDN $54,62 \%$. Komposisi dan kandungan nutrisi pakan penelitian pada Tabel 1. 
Tabel 1. Komposisi dan Kandungan Nutrisi Pakan Penelitian

\begin{tabular}{lcc}
\hline \hline \multirow{2}{*}{ Bahan Pakan } & \multicolumn{2}{c}{ Komposisi Pakan } \\
\cline { 2 - 3 } & T1 & T2 \\
\hline Rumput Kolonjono & 70 & 30 \\
Konsentrat & 30 & 70 \\
Kandungan Nutisi & & \\
Pakan Penelitian & & 16,39 \\
PK & 11,05 & 56,36 \\
TDN & 54,32 &
\end{tabular}

\section{rosedur penelitian}

Penelitian ini dibagi menjadi 5 tahap yaitu tahap persiapan 2 minggu meliputi persiapan ternak, 2 bulan tahap adaptasi, tahap pendahuluan, tahap perlakuan dan tahap pengambilan data. Pada tahap persiapan dilakukan persiapan ternak, persiapan peralatan, kandang, bahan pakan dan penyusunan pakan. Kambing Kejobong diperoleh dari peternak di Kecamatan Kejobong, Kabupaten Purbalingga yang kemudian diangkut dan dipelihara di kandang Kambing Fakultas Peternakan dan Pertanian Universitas Diponegoro, Semarang. Tahap pemulihan dan adaptasi dilakukan untuk mengembalikan kondisi tubuh ternak seperti keadaan awal setelah melakukan perjalanan dari Purbalingga menuju Semarang.

Tahap adaptasi dilakukan untuk membiasakan ternak dengan kondisi yang baru baik dengan fisiologi lingkungan maupun pakan yang akan dikonsumsi. Pemberian vitamin B kompleks dan obat cacing merk "Ivomex" masing-masing dengan dosis $5 \mathrm{ml}$ dan $0,2 \mathrm{ml}$ per $10 \mathrm{~kg}$ bobot badan agar kambing tidak terkena penyakit. Ternak diberi pakan dan minum secara ad libitum terlebih dahulu dengan tujuan untuk mengetahui kemampuan dalam mengkonsumsi pakan, pakan yang diberikan dalam bentuk mesh, lalu secara bertahap diadaptasikan terhadap pakan dalam bentuk pellet.

Tahap pendahuluan dilakukan pengacakan ternak dalam penempatan dalam kandang dan perlakuan pakan. Tahap pendahuluan dilakukan dengan tujuan untuk menghilangkan pengaruh dari pakan sebelumnya, tahap ini dilakukan selama 7 hari.Tahap perlakuan dilaksanakan selama 15 minggu. Pada tahap ini dilakukan penimbangan bobot badan awal. Pakan yang diberikan yaitu $4 \%$ bobot badan serta air minum diberikan secara adlibitum. Pemberian pakan dilakukan 4 kali sehari pada pukul 08.00, 12.00, 16.00, 20.00. Pada tahap perlakuan dilakukan pencatatan konsumsi pakan dengan cara menimbang pakan yang diberikan dan sisa pakan yang dikonsumsi, penimbangan bobot badan ternak setiap minggu untuk menyesuaikan jumlah pemberian pakan dan pada akhir tahap perlakuan 
dilakukan penimbangan bobot badan akhir untuk menghitung pertambahan bobot badan harian $(\mathrm{PBBH})$ selama tahap perlakuan.

Tahap pengambilan data meliputi dua tahap yaitu, persiapan dan pelaksanaan penelitian. Persiapan dilakukan dalam tiga tahap yaitu: tahap persiapan, pendahuluan dan tahap adaptasi, kemudian untuk pelaksanaan penelitian dilakukan dalam empat tahap yaitu: penyaringan starter, pengisisan digester, perhitungan bahan kering (BK) bahan organik (BO), pengisian substrat dan evaluasi produksi biogas feses.

Kegiatan persiapan yang dilakukan adalah menyiapkan alat-alat yang akan digunakan dalam pembuatan digester biogas tipe batch, seperti 2 botol kaca dengan ukuran $500 \mathrm{ml}, 1$ botol kaca dengan ukuran $1000 \mathrm{ml}$, karet penyumbat dengan diameter $3 \mathrm{~cm}$ yang sudah dilubangi, plastisin dan selang. Digester yang digunakan dapat dilihat pada Ilustrasi 1.

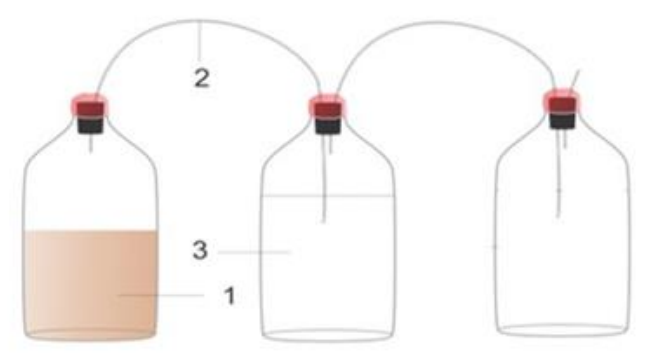

Keterangan :

1. Starter + Sampel

2. Selang Teflon

3. air

4. botol kosong

Ilustrasi 1. Rangkaian digester batch

Kegiatan pendahuluan yang dilakukan adalah, mengumpulkan feses dengan metode total koleksi selama 7 x 24 jam, kemudian setiap 24 jam sekali feses yang terkumpul ditimbang untuk mendapatkan berat feses, selanjutnya pengumpulan feses pada hari ke 7 digunakan untuk sampel sebanyak $1 \mathrm{~kg}$. Sampel kemudian disimpan di dalam alat pendingin selama 1 hari.

Kegiatan adaptasi yang dilakukan adalah, membuat starter dengan mencampurkan feses dan air dengan perbandingan 1:1, kemudian feses dan air diaduk hingga homogen selanjutnya drum ditutup hingga rapat. Pemeraman starter dilakukan selama 2 minggu untuk mengoptimalkan pertumbuhan bakteri methanogen. Feses dan air yang dicampur hingga homogen dengan perbandingan 1:1 kemdian disaring dengan menggunakan kain tipis. Cairan yang keluar pada saat proses penyaringan adalah cairan yang digunakan sebagai starter perkembanga untuk menghasilkan biogas. 
Pengisian digester adalah mengisi botol pertama dengan starter sebanyak $200 \mathrm{ml}$, kemudian botol ke dua berisi air sebanyak $1000 \mathrm{ml}$, kemudian botol-botol tersebut ditutup dengan menggunakan sumbat karet dan plastisin untuk mengkondisikan supaya dalam keadaan anaerob. Botol kaca ketiga yang kosong berfungsi sebagai tempat penampung air yang berpindah dan dianggap sebagai produksi biogas yang terbentuk.

Kegiatan perhitungan BK dan BO sampel dilakukan dengan mengggunakan oven dengan suhu $100{ }^{\circ} \mathrm{C}$ selama $6-7$ jam untuk mendapatkan hasil sampel bahan kering, setelah itu sampel ditimbang dengan menggunakan timbangan analitik dan selanjutnya sampel di masukan ke dalam tanur dengan suhu $550{ }^{\circ} \mathrm{C}$ selama 6 jam, setelah penanuran didapatkan sampel abu, sampel tersebut digunakan untuk perhitungan bahan organik sampel dengan cara presentasi BK dikurangi presentase abu, setelah penanuran didapatkan sampel abu, sampel tersebut digunakan untuk perhitungan bahan organik sampel dengan rumus:

\section{$\mathrm{BO}=\%$ bahan kering - \% abu}

Substrat yang dimasukkan ke dalam digester, kemudian substrat dan starter tersebut dihomogenkan. Pengukuran biogas dilakukan setiap minggu. Produksi biogas yang terbentuk dari botol pertama akan dialirkan melalui selang masuk ke dalam botol kedua yang berisi air, biogas yang terbentuk akan mendorong air, dan air akan mengalir menuju botol ketiga. Volume biogas diukur menggunakan metode liquid displacement method. Analisis data dilakukan dengan uji analysis of variant (ANOVA) untuk mengetahui pengaruh antara faktor A dan faktor B (Gomez dan Gomez, 2007).

\section{HASIL DAN PEMBAHASAN \\ Produksi Biogas}

Hasil penelitian menunjukan bahwa pakan dengan imbangan hijauan konsentrat yang berbeda menghasilkan produksi biogas yang berbeda nyata $(\mathrm{P}<0,05)$. Produksi biogas pada pakan $\mathrm{T} 2$ menghasilkan produksi biogas yakni $37,38 \mathrm{ml} / \mathrm{g} \mathrm{BO}$, sedangkan $\mathrm{T} 1$ memiliki produksi biogas yaitu, 46,55 ml/g BO (Tabel 2). Pada penelitian ini, perlakuan T1 memiliki imbangan rumput lebih tinggi dibandingkan dengan perlakuan T2. Hal tersebut menyebabkan tingginya kandungan serat kasar pada ransum T1 yakni $16,4 \%$. Kandungan serat kasar yang tinggi pada pakan akan menunjang pertumbuhan bakteri pembentuk metan. Apriliza (2013) menyatakan bahwa gas metan dihasilkan oleh serat kasar dan karbohirdrat yang difermentasi oleh bateri metanogenesis. Pakan dengan kandungan protein tinggi akan menghasilkan produksi biogas yang rendah, karena kebanyakan protein tidak baik untuk pertumbuhan bakteri.

Zulkarnaen et al, (2019) menyatakan bahwa banyaknya kandungan nitrogen $(\mathrm{N})$ pada feses akan menyebabkan berlebihnya amonia $\left(\mathrm{NH}_{3}\right)$ dan menyebabkan terhambatya pertumbuhan bakteri. Kelebihan unsur karbon (C) pada pembentukan biogas menyebabkan karbon (C) tidak bisa dicerna semua oleh bakteri. Kelebihan nitrogen $(\mathrm{N})$ meyebabkan berlebihnya amonia akan bersifat toxic pada bakteri dan menggagalkan pembentukan biogas. Rasio $\mathrm{C} / \mathrm{N}$ pada pembentukan biogas perlu adanya keseimbangan agar proses pembentukan biogas 
berjalan dengan stabil. Zulkarnaen et al. (2019) menyatakan bahwa keseimbangan rasio $\mathrm{C} / \mathrm{N}$ harus stabil agar proses pembentukan biogas berjalan stabil.

Tabel 2. Kualitas Feses dan Produksi Biogas

\begin{tabular}{clrrr}
\hline \hline \multicolumn{1}{c}{ Parameter } & \multicolumn{1}{c}{ Umur } & T1 & T2 & Rata - Rata \\
\hline \multirow{2}{*}{ Produksi Biogas (m1/g BO) } & Muda & 46,61 & 44,66 & $45,63^{\mathrm{x}}$ \\
\cline { 2 - 5 } & Dewasa & 46,48 & 30,51 & $38,49^{\mathrm{y}}$ \\
\cline { 2 - 5 } & Rata rata & $46,55^{\mathrm{a}}$ & $37,58^{\mathrm{b}}$ & \\
\hline \multirow{3}{*}{ Kadar PK Feses (\%) } & Muda & 6,85 & 6,59 & 6,72 \\
\cline { 2 - 5 } & Dewasa & 6,35 & 6,52 & 6,43 \\
\cline { 2 - 5 } & Rata rata & 6,60 & 6,61 & \\
\hline \multirow{2}{*}{ Kadar SK Feses (\%) } & Muda & 16,69 & 14,27 & $15,48^{\mathrm{a}}$ \\
\cline { 2 - 5 } & Dewasa & 16,11 & 12,72 & $14,41^{\mathrm{b}}$ \\
\cline { 2 - 5 } & Rata rata & $16,4^{\mathrm{a}}$ & $13,43^{\mathrm{b}}$ & \\
\hline
\end{tabular}

Keterangan : a,b Superskrip yang berbeda pada baris yang sama menunjukkan berbeda nyata $(\mathrm{P}<0,05)$

${ }^{\mathrm{x}, \mathrm{y}}$ Superskrip yang berbeda pada kolom yang sama menunjukkan berbeda sangat nyata $(\mathrm{P}<0,05)$

Perlakuan umur menunjukkan hasil yang berbeda nyata $(\mathrm{P}<0,05)$. Produksi biogas feses dari kambing muda menghasilkan biogas yaitu, 45,63 ml/g BO, sementara dari feses kambing dewasa menghasilkan biogas yaitu, 38,49 ml/g BO. Pada kambing muda dimana kondisi saluran pecernaan yang masih belum berkembang dengan optimal, sehingga pakan yang masuk belum diserap dengan optimal dan feses yang dikeluarkan mengandung BO yang tinggi. Hal ini didukung dengan nilai kecernaan pada kambing muda yang lebih rendah $(41,07 \%)$ dibanding dengan kambing dewasa (58,93\%).

Marhaeniyanto dan Susanti (2017) menyatakan bahwa kondisi pencernaan kambing muda masih dalam masa pertumbuhan sehingga penyerapan pakan belum maksimal. Pada kambing dewasa saluran pencernaan sudah dalam keadaan normal sehingga penyerapan nutrien pakan akan lebih optimal dibanding kambing muda. Kecernaan berpengaruh pada feses yang dihasilkan jika kecernaan pakan rendah maka bahan organik feses masih tinggi, sehingga kemungkinan produksi biogas yang tinggi. Dewi dan Dewi (2014) menyatakan bahwa kecernaan pakan yang rendah pada ternak dipengaruhi oleh pakan yang mengandung serat kasar yang tinggi.

\section{Produksi Feses}

Data mengenai produksi feses dan konsumsi BK ditampilkan pada Tabel 3. Perlakuan umur muda dan dewasa pada kambing tidak memberikan pengaruh pada produksi feses. Pada perlakuan pakan T1 menghasilkan feses $(1339,01 \mathrm{~g})$ dan perlakuan T2 menghasilkan feses $(1081,32 \mathrm{~g})(\mathrm{P}<0,05)$. Tingginya serat kasar pada perlakuan $\mathrm{T} 1$ menyebabkan kecernaan pada $\mathrm{T} 1$ rendah $(43,42 \%)$. Rendahnya kecernaan menyebabkan tingginya produksi feses. 
Herawati dan Wibawa (2010) yang menyatakan bahwa pakan yang serat kasarnya tinggi akan sulit dicerna oleh ternak. Paramita et al. (2008) menyatakan bahwa kecernaan pakan dipengaruhi oleh jumlah dan kandungan nutrien dalam pakan yang dikonsumsi ternak. Kecernaan yang tinggi pada perlakuan T2 $(54,24 \%)$ disebabkan kandungan serat kasar yang rendah pada pakan perlakuan T2 yakni (17,60\% BK). Tillman et al., (1991) menyatakan bahwa serat kasar tersusun dari selulosa dan hemiselulosa merupakan bahan yang sulit dicerna di dalam saluran pencernaan.

Hasil penelitian menunjukkan bahwa konsumsi bahan kering baik pada umur muda maupun dewasa tidak berbeda nyata $(1,002 \mathrm{~kg} \mathrm{BK})$. Hal tersebut menyebabkan produksi feses yang dihasilkan pada penelitian ini juga tidak berbeda nyata $(\mathrm{P}<0,05)$. Susilo $(2010)$ menyatakan bahwa feses yang dihasilkan dipengaruhi oleh kemampuan ternak dalam mengkonsumsi pakan. Konsumsi yang sama pada umur yang tidak berbeda nyata disebabkan bobot badan pada T1 dan T2 tidak berbeda nyata $(22,2 \mathrm{~kg})$. Banyaknya feses yang dihasilkan dipengaruhi oleh tingkat konsumsi BK.

Tabel 3. Total Produksi BK Feses dan Konsumsi BK

\begin{tabular}{llccc}
\hline \hline \multicolumn{1}{c}{ Parameter } & Umur & T1 & T2 & Rata - Rata \\
\hline \multirow{2}{*}{ Produksi Feses (g) } & Muda & 1112,71 & 1173,05 & 1106,85 \\
& Dewasa & 1543,21 & 1083,75 & 1313,48 \\
& Rata rata & $1339,01^{\mathrm{a}}$ & $1081,32^{\mathrm{b}}$ & \\
\hline \multirow{2}{*}{ Konsumsi Bahan Kering } & Muda & 0,796 & 1,008 & 0,902 \\
(kg BK) & Dewasa & 1,056 & 1,150 & 1,103 \\
& Rata rata & $0,926^{\mathrm{b}}$ & $1,079^{\mathrm{a}}$ & \\
\hline
\end{tabular}

Keterangan : ${ }^{\mathrm{a}, \mathrm{b}}$ Superskrip yang berbeda pada baris yang sama menunjukkan berbeda nyata $(\mathrm{P}<0,05)$

\section{KESIMPULAN DAN SARAN}

Berdasarkan penelitian ini, dapat disimpulkan bahwa pakan perlakuan T1 menghasilkan jumlah feses (1339,01 g), dan produksi biogas (46,55 ml/g BO). Pada perlakuan T2 menghasilkan produksi feses (1081,32 g) dan menghasilkan produksi biogas $(37,58 \mathrm{ml} / \mathrm{g} \mathrm{BO})$. Pada perlakuan umur muda menghasilkan produksi feses $(1106,85 \mathrm{~g})$ dan menghasilkan produksi biogas $(45,63 \mathrm{ml} / \mathrm{g} \mathrm{BO})$. Pada perlakuan umur dewasa menghasilkan produksi feses $(1313,48 \mathrm{~g})$ dan menghasilkan produksi bioga $(38,49 \mathrm{ml} / \mathrm{g}$ BO). Berdasarkan hasil penelitian, untuk menghasilkan biogas yang lebih banyak $(46,09 \mathrm{ml} / \mathrm{g} \mathrm{BO})$, sebaiknya menggunakan kambing muda yang diberi pakan perlakuan $\mathrm{T} 1$.

\section{DAFTAR PUSTAKA}

Apriliza, M.N. 2013. Deposisi energi pada kambing kacang yang diberi pakan dengan imbangan protein-energi yang berbeda. Jurusan Peternakan. Fakultas Peternakan dan Pertanian. Universitas Diponegoro. Semarang. (Skripsi) 
Dewi, T. K. dan C. K. Dewi. 2014. Pembatan gas bio dari serbuk gergaji, kotoran sapi, dan larutan EM4. J. Teknik Kimia 1 (20): 1-9.

Gomez, K., A., Gomez, A., A., 2007. "Prosedur statistik untuk penelitian pertanian”, Translated by Sjamsuddin, E., and Baharsjah, J., S, UI Press, Jakarta, Indonesia, 2007

Herawati, D.A. dan A. A. Wibawa. 2010. Pengaruh pretreatment jerami padi pada produksi biogas dari jerami padi dan sampah sayur sawi hijau secara batch. J. Rekayasa Proses,4(1): 25-29.

Kusuma, A., Purnomoadi, A., Al-Barri, A.N. 2013. Perbandingan persentase kulit antara kambing kejobong, kambing peranakan ettawah dan kambing kacang jantan umur satu tahun. Animal Agriculture Journal, Vol. 2. No. 1, 2013, P $114-119$.

Marhaeniyanto dan S. Susanti., 2017.Penggunaan daun Gamal, Lamtoro, Kaliandra dan Nangka dalam Konsentrat untuk meningkatkan penampilan Kambing Pejantan Muda.Seminar Nasional Hasil penelitian Universitas Kanjuruhan Malang. Malang. 193 - 203.

Nabila, F. 2017. Potongan komersial karkas domba muda lokal jantan yang diberi pakan komplit dengan level protein dan total digestible nutrients berbeda. Skripsi. Fakultas Peternakan dan Pertanian. Undip.

Nuraeni, I. G. S. Budisatria dan A. agus. 2014. Pengaruh tinggkat penggunaan pakan penguat terhadap performa induk kambing bligon di peternakan rakyat. Bulletin Peternakan. 38 (1) : $32-41$.

Paramita, W. L., W. E. Susanto, dan A. B. Yulianto. 2008. Konsumsi dan kecernaan bahan kering dan bahan organik dalam haylase pakan lengkap ternak sapi Peranakan Ongole. Media Kedokteran Hewan 24: 59-62.

Siregar, I. P. 2018. Pertambahan Bobot Badan Kambing Jawarandu Pada Tingkatan Umur Yang Berbeda Di Usaha Peternakan Kambing "Go Farm”. Universitas Brawijaya. Malang. (Skripsi).

Susilo, H. J., 2010. Pengaruh Substitusi Konsentrat dengan Tepung Umbi Suweg dalam Ransum terhadap Nilai Cerna Ransum pada Kelinci New Zealand White Jantan. Jurusan Peternakan, Fakultas Pertanian. Universitas Sebelas Maret. Surakarta. (Skripsi). 
Tillman, A. D., H. Hartadi, S. Reksohadiprojo, S. Prawirokusumo dan S. Lebdosukodjo. 1991. Ilmu makanan ternak dasar. Gadjah Mada University Press, Yogyakrta.

Zulkarnaen, I. R. Tira dan H. Padagg. Y. A. 2019. Pegaruh rasio karbon dan nitrogen pada kotoran sapi terhadap produksi biogas dari proses anaerob. J. Dinamika teknik mesin. 1 - 16. 